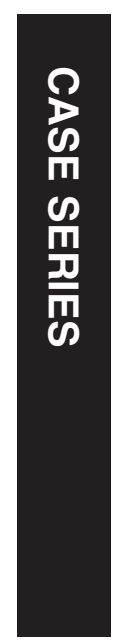

\section{Larger and near-term baby retinopathy: a rare case series}

${ }^{1}$ Retina-Vitreous Services, L V Prasad Eye Institute, Bhubaneswar, India

${ }^{2}$ Srimati Kanuri Santhamma Centre for Vitreoretinal Diseases, L V Prasad Eye Institute, Hyderabad, India

${ }^{3}$ Infosys Pediatric Center, Capital Hospital,

Bhubaneswar, India

${ }^{4}$ Department of Pediatrics, Kalinga Institute of Medical Sciences, Bhubaneswar, India

${ }^{5}$ Pediatric Unit, Jagannath Hospital, Bhubaneswar, India

Correspondence: TR Padhi, Retina-Vitreous Services, LV Prasad Eye Institute, Patia, Bhubaneswar, Odisha 751 024, India Tel: +91 674 3989202; Fax: +916743987130 E-mail: tapas@lvpei.org or drtapasranjan@yahoo.co.in

Received: 30 January 2014 Accepted in revised form: 23 September 2014 Published online: 31 October 2014

\begin{abstract}
Purpose To report retinopathy in a series of four babies unusually beyond the screening standards reported so far in the literature. Methods During routine screening for retinopathy of prematurity, we detected retinopathy in four babies who were surprisingly bigger and older than the screening standards. The gestational age (GA), birth weight (BW), post menstrual age at first examination and significant perinatal events were noted. The retinopathy details imaged by the RetCam were classified as per ICROP revisited standards. Result The GA ranged from 36 to 39 weeks and BW from 2.4 to $3.0 \mathrm{~kg}$. Three of them had retinopathy in zone III that regressed spontaneously and one had marked plus with vascular arcades and shunts in zone II that regressed after laser photocoagulation. All of them had fetal distress and multiple systemic comorbidities in the neonatal period.

Conclusion This report makes one aware of the possibility of retinopathy in newborn of older GA and larger BW especially with fetal distress and stormy neonatal course. Eye (2015) 29, 286-289; doi:10.1038/eye.2014.253; published online 31 October 2014
\end{abstract}

\section{Introduction}

Screening criteria for retinopathy of prematurity (ROP) vary from place to place. The American guidelines for ROP screening ${ }^{1}$ includes babies $\leq 1500 \mathrm{~g}$ birth weight (BW) or $\leq 32$ weeks gestational age (GA); screening of infants $>1500 \mathrm{~g}$ BW or $>32$ weeks GA is left to the discretion of the attending neonatologist. There are many reports of babies with higher $\mathrm{BW}$ and longer GA being affected with ROP. ${ }^{2-6}$ However
TR Padhi', S Rath', S Jalali², L Pradhan³, S Kesarwani', M Nayak ${ }^{4}$, B Mishra $^{5}$, KG Panda ${ }^{1}$ and S Suttar ${ }^{1}$
ROP developing in term or near-term babies at BW between 2.4 and $3.0 \mathrm{~kg}$ in the present series has rarely been well documented and reported in the literature.

\section{Case reports}

We detected retinopathy in four babies who were older and heavier than our screening standards (Table 1). The demographic details including GA, BW,and post menstrual age (PMA) at first examination and significant perinatal events including mode and duration of oxygen supplementation were noted. The retinopathy details imaged by the RetCam (Clarity Medical Systems, Pleasanton, CA, USA) were classified as per ICROP revisited standards. ${ }^{7}$ As majority of them were neither premature nor had low BW we called them as 'larger and near-term baby retinopathy'.

Case 1 (GA 39 weeks, BW $3.0 \mathrm{~kg}$ )

Referred for screening at 43 weeks of PMA, the child had stage 2 ROP extending up to 1-2 clock hours in zone III in both the eyes (Figure 1a and b). The retinopathy regressed completely by 48 weeks of PMA.

\section{Case 2 (GA 37 weeks, BW $3.0 \mathrm{~kg}$ )}

Screened at 39 week of PMA, there was poor mydriasis with dilatation and tortuosity of posterior pole vessels in zone II with shunting and arcading (Figure 1c) similar to aggressive posterior ROP. The retinopathy regressed completely by 45 weeks of PMA following three sittings of laser treatment.

Case 3 (GA 36 weeks, BW $2.4 \mathrm{~kg}$ )

Born by caeserean section for fetal distress, apnea developed $1 \mathrm{~h}$ after birth for which she 
Table 1 Summary of the four cases in brief

\begin{tabular}{|c|c|c|c|c|}
\hline & Significant perinatal events & $\begin{array}{l}P M A \text { at } \\
\text { presentation }\end{array}$ & ROP status & Treatment and outcome \\
\hline $\begin{array}{l}\text { Case } 1 \text { : } \\
\text { GA } 39 \text { weeks } \\
2 \text { days } \\
\text { BW } 3.0 \mathrm{~kg}\end{array}$ & $\begin{array}{l}\text { CS delivery following fetal distress in third } \\
\text { trimester. } \\
\text { Meconium aspiration, birth asphyxia,apnea, } \\
\text { and sepsis. Oxygen supplementation for } 10 \\
\text { days (intubation:7 days, oxygen hood:3 days) }\end{array}$ & $\begin{array}{l}43 \text { weeks } \\
2 \text { days }\end{array}$ & $\begin{array}{l}\text { (OU) Stage } 2 \text { ROP, } 1-2 \\
\text { clock hours in zone III, } \\
\text { no plus }\end{array}$ & $\begin{array}{l}\text { Spontaneous regression } \\
\text { by } 48 \text { weeks of PMA. } \\
\text { No recurrence in } \\
\text { subsequent visits }\end{array}$ \\
\hline $\begin{array}{l}\text { Case } 2 \text { : } \\
\text { GA } 37 \text { weeks } \\
3 \text { days } \\
\text { BW } 2.7 \mathrm{~kg}\end{array}$ & $\begin{array}{l}\text { Vaginal delivery. Severe respiratory distress on } \\
\text { day } 3 \\
\text { oxygen supplementation for } 15 \text { days (CPAP:13 } \\
\text { days, oxygen hood: } 2 \text { days) }\end{array}$ & $\begin{array}{l}38 \text { weeks } \\
4 \text { days }\end{array}$ & $\begin{array}{l}\text { (OU) Poor mydriasis, } \\
\text { marked dilatation and } \\
\text { tortuosity of posterior } \\
\text { pole vessels with } \\
\text { arcading and shunting } \\
\text { in zone II }\end{array}$ & $\begin{array}{l}\text { Regressed after three } \\
\text { sittings of laser by } 45 \\
\text { weeks of PMA. No } \\
\text { recurrence thereafter }\end{array}$ \\
\hline $\begin{array}{l}\text { Case 3: } \\
\text { GA } 36 \text { weeks } \\
2 \text { days, } \\
\text { BW } 2.4 \mathrm{~kg}\end{array}$ & $\begin{array}{l}\text { CS delivery for fetal distress. Oxygen } \\
\text { supplementation for } 17 \text { days (intubation } 15 \\
\text { days, Oxygen hood } 2 \text { days). Transfused with } \\
\text { packed red blood cells twice and fresh frozen } \\
\text { plasma thrice for anemia secondary to severe } \\
\text { gastro intestinal hemorrhage }\end{array}$ & 40 weeks & $\begin{array}{l}\text { Zone III, stage } 2 \text { pre } \\
\text { plus }\end{array}$ & $\begin{array}{l}\text { (OU) Spontaneous } \\
\text { regression by } 44 \text { weeks } \\
\text { and no recurrence } \\
\text { thereafter. }\end{array}$ \\
\hline $\begin{array}{l}\text { Case } 4 \text { : } \\
\text { GA } 37 \text { weeks, } \\
\text { BW } 3.0 \mathrm{~kg}\end{array}$ & $\begin{array}{l}\text { Delivered on the way to the hospital, mother } \\
\text { died of severe blood loss. The child did not cry } \\
\text { for } 3 \mathrm{~h} \text { after birth. Oxygen supplementation } \\
\text { (intubation) for } 5 \text { days for severe apnea }\end{array}$ & 39 weeks & $\begin{array}{l}\text { Multiple retinal } \\
\text { hemorrhages in both } \\
\text { eyes and preretinal } \\
\text { hemorrhage in the right } \\
\text { eye. In addition, there } \\
\text { was a ridge in zone III } \\
\text { for } 4 \text { clock hours in } \\
\text { right eye (Figure 2a) } \\
\text { and for } 1 \text { clock hour in } \\
\text { the left eye }\end{array}$ & $\begin{array}{l}\text { (OU) Hemorrhages } \\
\text { disappeared, ridge got } \\
\text { progressively displaced } \\
\text { and finally regressed } \\
\text { by } 45 \text { weeks }\end{array}$ \\
\hline
\end{tabular}

was ventilated for $48 \mathrm{~h}$, followed by oxygen supplementation for 15 days. She was transfused with packed red blood cells twice and fresh frozen plasma thrice for anemia secondary to severe gastro intestinal hemorrhage. At 40 weeks of PMA, both eyes had zone III, Stage 2 pre-plus ROP (Figure 1d) that regressed completely by 44 weeks of PMA.

\section{Case 4 (GA 37 week, BW $3.0 \mathrm{~kg}$ )}

Examined at 39 weeks of PMA, there were multiple retinal hemorrhages (Figures $2 a$ and $b$ ) in both the eyes and preretinal hemorrhage in the right eye mostly seondary to birth asphyxia. In addition, there was a ridge in zone III in both the eyes (Figure 2). The hemorrhages resolved, ridge got progressively displaced, and finally disappeared in both eyes in the subsequent visits (Figures 2c and d).

\section{Discussion}

To find retinopathy in these older and heavier babies was quite surprising and raises queries on the accuracy of diagnosis, GA, and BW details.

The authors were cautious and aware of conditions mimicking ROP. The fact that the ridge and the retinopathy regressed in all and that the family members had unremarkable fundus ruled out familial exudative vitreoretinopathy where the retina remains avascular. No other congenital associations ruled out many other mimickers. In all four babies, the GA was accurately ascertained on the basis of last menstrual period and cross verified with available written expected date of delivery, first-trimester fetal ultrasonography and pediatricians' assessment. The BW was ascertained from the pediatricians' record and cross checked with the weight noted on the subsequent visits and from delivery records. Several hypotheses may explain the unexpected development of ROP in these children. All children had fetal distress in the last trimester, had stormy neonatal course with multiple comorbidities and were referred to the ophthalmologist by the pediatrician on the high index of risk of retinopathy despite older age and higher BW. In fact some of them could have been missed had we adhered to the existing screening criteria without the risk factors. We hypothesize that certain maternal and fetal factors could have lead to inadequate peripheral retinal vascularization despite being large and near term at birth. This would have made the soil ready for development of retinopathy by the multiple comorbidities in the postnatal period including prolonged oxygen supplementation. A routine retinal 
a

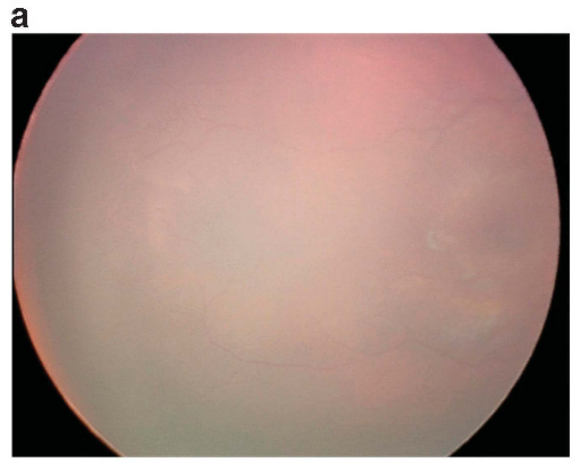

C

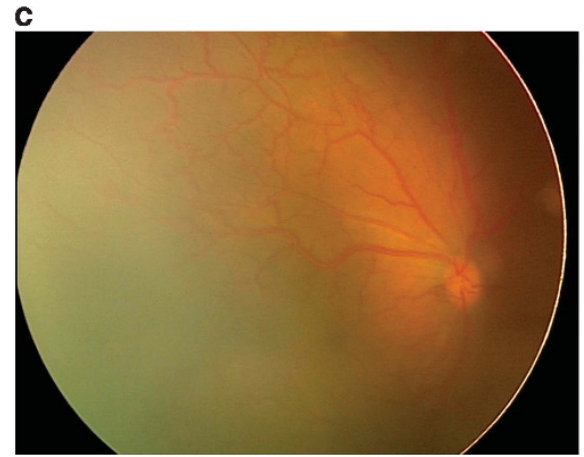

b

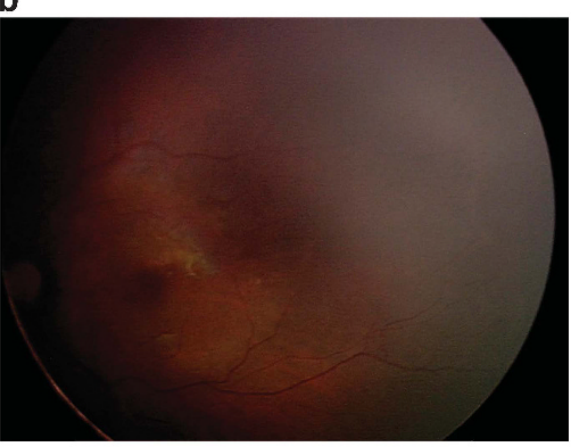

d

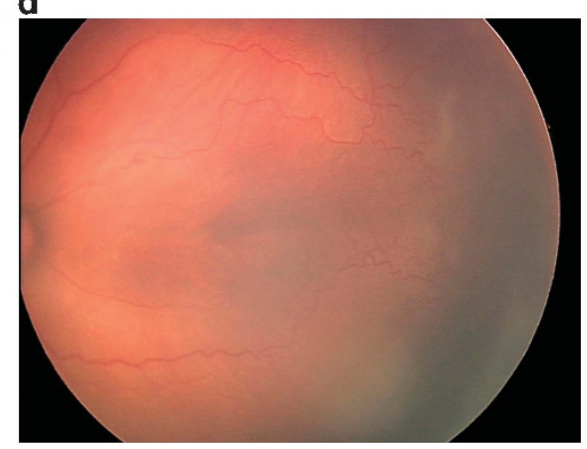

Figure 1 Composite fundus picture of ROP findings of cases 1, 2, and 3. (a and b) Fundus picture of right and left eye, respectively (case 1) showing a ridge in zone III. (c) Fundus picture of right eye (case 2) showing markedly dilated and tortuous vessels involving the posterior pole with arcading and shunting of blood vessels in zone II. (d) Fundus picture of the left eye (case 3) showing a ridge in zone III.

a

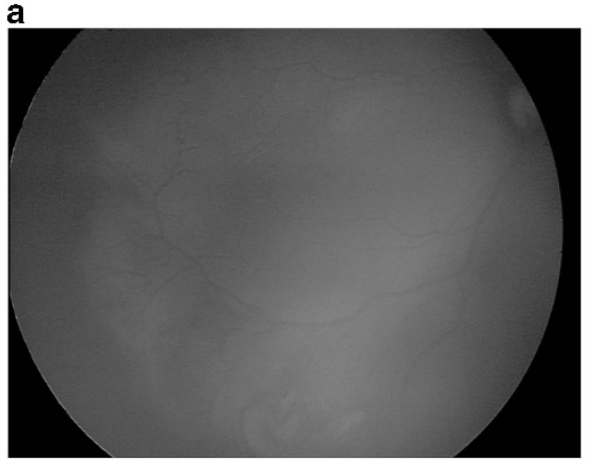

c

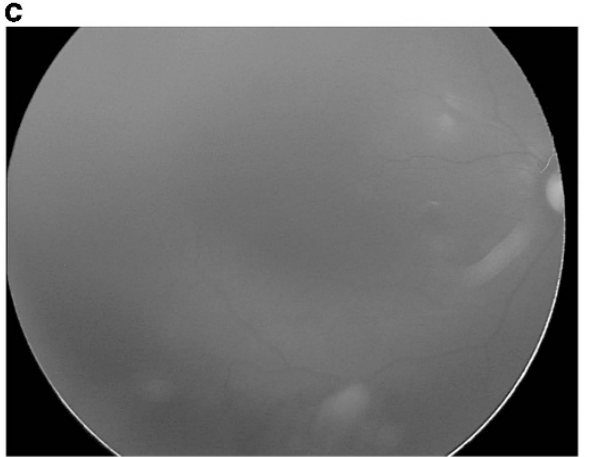

b

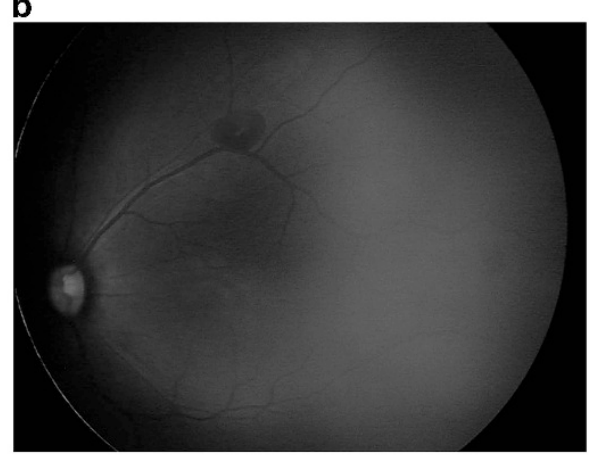

d

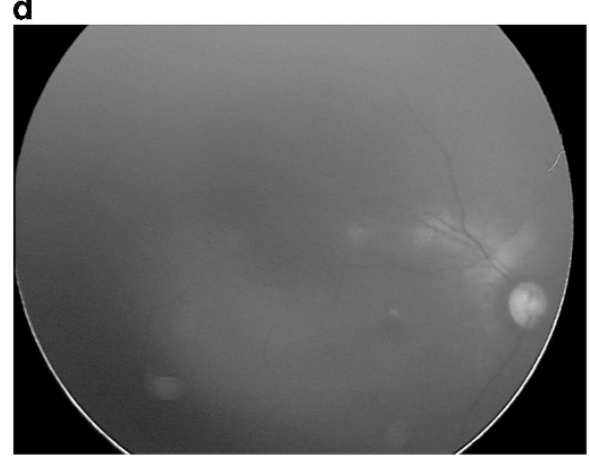

Figure 2 Fundus images showing the disease course of case 4. (a) Fundus picture of the right eye showing a ridge in zone III for 4 clock hours temporally in addition to retinal and preretinal hemorrhages. (b) Fundus images of the left eye showing ridge in zone III for 1 clock hour in addition to retinal hemorrhages. (c and d) Fundus of the right eye showing disappearance of the ridge in subsequent visits. 
screening of such babies at birth to tally the extent of retinal maturity with respect to their GA could be an interesting alternative. As all of them received oxygen, details on the arterial oxygen saturation, its fluctuation and subsequent correlation with the retinopathy if any could have been more informative.

\section{Summary}

What was known before

- Babies born prematurely and/or with lowBW are known to develop ROP. The GA and BW criteria for ROP vary from 30 to 34 weeks and from 1500 to $1750 \mathrm{gm}$ in West to East. Retinopathy developing in babies born at term/near term and/or BW $>2.4 \mathrm{~kg}$ has rarely been well documented/reported in the literature.

\section{What this study adds}

- It is not unusual to see retinopathy in term or near-term babies and at a higher BW especially in babies with fetal distress and a stormy neonatal course. Certain maternal and fetal factors are responsible in keeping the retina immature despite being large term or near term at birth.

\section{Conflict of interest}

The authors declare no conflict of interest.

\section{References}

1 Section on Ophthalmology American Academy of Pediatrics, American Academy of Ophthalmology, American Association for Pediatric Ophthalmology and Strabismus. Screening examination of premature infants for retinopathy of prematurity. Pediatrics 2006; 117: 572-576.

2 Vinekar A, Dogra MR, Gupta A. Retinopathy of prematurity in Asian Indian babies weighing greater than 1250 grams at birth: ten year data from a tertiary care center in a developing country. Indian J Ophthalmol 2007; 55: 331-336.

3 Shah PK, Narendran V, Kalpana N. Aggressive posterior retinopathy of prematurity in large preterm babies in South India. Arch Dis Child Fetal Neonatal Ed 2012; 97: F371-F375.

4 Shah PK, Narendran V, Kalpana N, Gilbert C. Severe retinopathy of prematurity in big babies in India: history repeating itself? Indian J Pediatr 2009; 76(8): 801-804

5 Jalali S, Matalia J, Hussain A, Anand R. Modification of screening criteria for retinopathy of prematurity in India and other middle-income countries. Am J Ophthalmol 2006; 141: 966-968.

6 Jandeck C, Kellner U, Kossel H, Bartsch M, Versmold HT, Froester H. Retinopathy of prematurity in infants of birth weight $>2000 \mathrm{~g}$ after haemorrhagic shock at birth. Br J Ophthalmol 1996; 80: 728-731.

7 An International Committee for Classification of Retinopathy of Prematurity. The international classification of retinopathy of prematurity revisited. Arch Ophthalmol 2005; 123: 991-999. 